\title{
PREVALENCE OF HUMAN HERPESVIRUS 8 ANTIBODIES IN THE POPULATION OF BELÉM, PARÁ, BRAZIL
}

\begin{abstract}
SUMMARY
Serum samples from 497 children and adults inhabiting two neighbourhoods (Guamá and Terra Firme) in Belém, Pará, North Brazil were screened for the presence of human herpesvirus 8 (HHV-8) antibody using an enzyme-linked immunosorbent assay. An overall $16.3 \%$ prevalence was found for these urban communities. Taken both genders together, prevalence rates of HHV-8 antibody increase gradually, across age-groups, ranging from $12.0 \%$ to $33.3 \%$. When seroprevalence is analysed by gender, similar rates are found for female $(18.4 \%)$ and male $(14.0 \%)$ individuals. In the former gender group, seroprevalence rates increased from $10.3 \%$, in children $\leq 10$ years of age, to $30.0 \%$ in adults $41-50$ years of age. Conversely, among male subjects, the prevalence of HHV-8 antibodies decreased from $13.3 \%$ in children/young adults aged $\leq 10$ to 20 years of age to $6.1 \%$ in adults aged 21-30 years. From the 31-40 year-old group male onwards, seropositivity rates increased gradually, ranging from $8.3 \%$ to $66.7 \%$. A significant difference in seropositivity rates was noted when comparing 21-30 age groups for female and male subjects: $23.3 \%$ and $6.1 \%$, respectively $(\mathrm{P}=$ 0.03 ). Geometric mean optical densities were found to increase slightly from the lower to the higher age-groups. Our data suggest that transmission of HHV-8 occurs frequently in the general urban population of Belém, and that prevalence of antibody seems to increase with age.
\end{abstract}

KEYWORDS: Prevalence; Human Herpesvirus 8; Urban population.

\section{INTRODUCTION}

Human herpesvirus 8 (HHV-8), also known as Kaposi's sarcoma herpesvirus (KSHV), was discovered by CHANG et al. $(1994)^{13}$ as a KS-specific DNA fragment. HHV-8 that belongs to the Rhadinovirus, or gamma-2 herpesvirus, genus within the subfamily Gammaherpesvirinae $e^{12,32}$.

HHV-8 DNA sequences have been detected in peripheral blood lymphocytes of HIV-positive individuals with or without $\mathrm{KS}^{10,21,22,48}$, in B-cell body cavity lymphomas ${ }^{9,18,37}$, in uroepithelial cells of healthy immunocompetent individuals ${ }^{31}$, in HIV-1 negative patients with Bowen's disease $^{21}$, in multicentric Castleman's disease ${ }^{18,21}$, in prostate tissue and in human semen ${ }^{7,20,31}$. HHV-8 has also been associated with other tumors, including angiosarcomas, hemangiomas, malignant squamous cell carcinomas and actinic keratosis ${ }^{23}$. This virus was also recently reported to infect healthy blood donors 5 . The presence of HHV-8 DNA in tonsillar swabs and saliva ${ }^{11,14,15}$ suggests that the virus replicates in tonsils and then is sheds in saliva, which would contribute to HHV-8 transmission. This was also observed for the others herpesviruses ${ }^{15,16}$.

Seroepidemiological studies suggest that HHV-8 has two major modes of transmission: sexual and non-sexual. The latter route of transmission involves body fluids such as nasal secretions, saliva and blood therefore explaining the ample distribution of HHV-8 in many areas of the world $5,6,24,28,38,43,45$.

HHV-8 is known to have a worldwide occurrence but infection rates vary according to a combination of geographic and behavioural risk factors ${ }^{2,37}$. HHV-8 antibody titers among infected healthy adults were found to be higher in regions with high HHV-8 seroprevalence rates and where KS disease is common ${ }^{17,33}$. In African populations with high rates of endemic KS, the prevalence of HHV-8 antibody in adults ranges from 30 to $60 \% \%^{1,33,40}$. In contrast, seroprevalence rates among healthy heterosexual adults in North American and European populations are reported to be generally low, of $1-2 \%{ }^{17,39}$. Intermediate prevalence rates of HHV-8 antibodies among adults have been reported for Italy and Greece (20-35\%) $)^{9,42,44,46}$, whereas HHV-8 prevalence in Central American and Caribbean populations has been reported to range between 10 and $29 \% 19,25,41$

In Brazil, the prevalence of HHV-8 antibodies in the general populations has not yet been established. Indeed, studies carried out to date in Brazil have focussed on population groups that would theoretically be at increased risk of acquiring HHV-8 infection. Two of these studies have focussed on HHV-8 infection among HIV-positive patients with or 
without $\mathrm{KS}^{10,22,49}$. In this context, it has been demonstrated that the prevalence of HHV-8 antibody is higher among HIV-1 infected gay men with KS, as compared with other Brazilian groups. Of importance, an epidemiological survey conducted by ZAGO et al. ${ }^{48}$, (2000) in Southeastern Brazil yielded HHV-8 antibody rates to latent nuclear antigens of $80 \%$ among HIV-positive patients with KS, whereas much lower, but similar seropositivity rates, were found for HIV-positive patients without KS (14.6\%) and casualty patients (9.6\%).

Recent seroepidemiological studies among remote Amerindian communities living in Northern Brazil - using an immunofluorescence test for latent antibody - showed an unusually high, overall 53\% prevalence. In addition to this, a new HHV-8 E subtype was found to be hyperendemic in these Amerindians, although KS has not been reported to occur among them ${ }^{3}$.

The present investigation dealt with the prevalence of HHV-8 antibody [immunoglobulin $\mathrm{G}$ class $(\operatorname{IgG})$ ] in normal populations inhabiting two neighbouring, crowded districts of Belém, Northern Brazil.

\section{MATERIALS AND METHODS}

The present study involved 81 low-income families - including 497 subjects - living in 2 neighbourhoods ("Guamá" and "Terra Firme") of Belém, Brazil. These families were randomly selected from records of a previous rotavirus vaccine field trial conducted at the same site (LINHARES, et al. $\left.{ }^{26}, 1996\right)$. Blood samples were drawn - by antecubital venepuncture - from all individuals $(n=497)(236$ of whom were male) from August to December 1994. Infants aged less than six months were not enrolled to participate in this study. Overall, ages ranged from 7 months to 70 years (mean, 18 years, $S D=15$ ). All sera were stored frozen, at $-20{ }^{\circ} \mathrm{C}$, until (anonymously) processed for the presence of HHV-8 antibody.

Detection of IgG antibodies to HHV-8 was made using a commercial enzyme-linked immunosorbent assay (ELISA) developed by ADVANCED BIOTECHNOLOGIES ${ }^{\mathrm{TM}}$ (Columbia, Maryland, USA). This is an assay that includes solid-phase multiple-well strips coated with solubilized HHV-8 whole virus extract isolated from the KS-1 cell line ${ }^{35}$. The KS-1 cell line is derived from a body cavity lymphoma, as previously described ${ }^{36}$. Sera were tested at a (single) dilution of 1:100, according to manufacturer's instructions. ELISA results were calculated dividing optical density (O.D.) values of serum samples by the mean absorbance of cut-off. Serum samples yielding O.D. ratios of $\geq 1.00$ were ranged as positive.

The data were analyzed using the EPI-INFO software version 6.0 (Atlanta, GA, USA). Rates were compared using the Mantel-Haenszel chi-square test of association or Fisher's exact test, when applicable. Significance was defined as $\mathrm{P}<0.05$.

\section{RESULTS}

Overall, 16.3\% (81/497) of tested persons had HHV-8 antibody, with prevalence rates increasing from $12.0 \%$ to $33.3 \%$ across age groups (Table 1). Taking all age-groups together, similar seroprevalence rates were found for women and men: $18.4 \%$ and $14.0 \%$, respectively. Increasing percentages of HHV-8 antibody were observed in women from the first $(10.3 \%)$ to the fifth age groups, and a comparatively low prevalence, $20 \%$, was found among individuals over 50 years of age. Among male subjects the prevalence of HHV-8 antibody decreased from $13.3 \%$, in children/young adults aged $\leq 10$ to 20 years, to $6.1 \%$ in adults aged 21 30 years. In the following age groups, $8.3 \%$ positivity was detected in adults aged $31-40$ years, rising to $66.7 \%$ in the age group $>50$ years. A significant difference in prevalences was detected when comparing female and male individuals aged $21-30$ years: $23.3 \%$ and $6.1 \%$, respectively $(\mathrm{P}=0.03)$. Serum anti-HHV-8 IgG concentrations - as measured by geometric mean optical densities (GMODs) according to age groups, are shown in Table 2. GMOD values increased slightly from the first to the fourth age groups (range, 1.5 to 1.9), decreasing across age-groups of more than 40 years. Overall GMODs for Female tended to be higher than those for Male: 1.8 and 1.5, respectively.

Table 1

Prevalence of antibody to HHV-8 according to age and gender in Belém, Pará, Brazil

\begin{tabular}{|c|c|c|c|c|}
\hline \multirow[b]{2}{*}{$\begin{array}{l}\text { Age groups } \\
\text { (years) }\end{array}$} & \multicolumn{4}{|c|}{ No. of sera positive/No. tested (\%) } \\
\hline & \multicolumn{2}{|c|}{ Total } & Female & Male \\
\hline$\leq 10$ & $26 / 217$ & $(12.0 \%)$ & $10 / 97(10.3 \%)$ & $16 / 120(13.3 \%)$ \\
\hline $11-20$ & $16 / 92$ & $(17.4 \%)$ & $10 / 47(21.3 \%)$ & $6 / 45 \quad(13.3 \%)$ \\
\hline $21-30$ & $16 / 93$ & $(17.2 \%)$ & $14 / 60(23.3 \%)^{\mathrm{a}}$ & $2 / 33(6.1 \%)^{b}$ \\
\hline $31-40$ & $10 / 56$ & $(18.0 \%)$ & $8 / 32(25.0 \%)$ & $2 / 24 \quad(8.3 \%)$ \\
\hline $41-50$ & $6 / 18$ & $(33.3 \%)$ & $3 / 10(30.0 \%)$ & $3 / 8 \quad(37.5 \%)$ \\
\hline$>50$ & $7 / 21$ & $(33.3 \%)$ & $3 / 15(20.0 \%)$ & $4 / 6 \quad(66.7 \%)$ \\
\hline Total & $81 / 497$ & $(16.3 \%)$ & $48 / 261(18.4 \%)$ & $33 / 236(14.0 \%)$ \\
\hline
\end{tabular}

Table 2

Distribution of geometric mean optical densities of HHV-8 antibody according to age and gender in Belém, Pará, Brazil

\begin{tabular}{llll}
\hline & \multicolumn{3}{c}{ Geometric mean optical densities } \\
Age (years) & Female & Male & Total \\
\hline$\leq 10^{\mathrm{a}}$ & $1.5(97)$ & $1.6(120)$ & $1.5(217)$ \\
$11-20$ & $1.8(47)$ & $1.5(45)$ & $1.7(92)$ \\
$21-30$ & $1.9(60)$ & $1.3(33)$ & $1.8(93)$ \\
$31-40$ & $1.9(32)$ & $2.3(24)$ & $1.9(56)$ \\
$41-50$ & $2.0(10)$ & $1.2(8)$ & $1.5(18)$ \\
$>50$ & $1.7(15)$ & $1.9(6)$ & $1.8(21)$ \\
\hline Total & $1.8(261)$ & $1.5(236)$ & $1.7(497)$ \\
\hline
\end{tabular}

${ }^{a}$ All children in this age-group were older than 6 months.

\section{DISCUSSION}

Recent studies ${ }^{2,17,35,37}$ have indicated a great variability in the HHV8 antibody prevalence in different geographic areas worldwide. Serological and molecular studies suggest that HHV-8 may be largely distributed in the human population and, like other herpesviruses, it has 
the potential of infecting latently tissues and body fluids, until reactivation $^{4,11,25,27,38}$. Worldwide, recent serosurveys indicate that HHV8 infection rates in various populations vary considerably, according to a combination of geographic and behavioural factors ${ }^{2,17,35,37,38}$. In Brazil, very few studies have dealt with the epidemiology of HHV-8 infection in the general population. In fact, most of these investigations have focussed on specific, high-risk groups of the population, such as those represented by HIV-seropositive individuals with or without $\mathrm{KS}^{10,22,48,49}$.

The goal of the present study was therefore to determine the prevalence of HHV-8 antibodies in Belém, Brazil, regardless of the target population's HIV serological status. To our knowledge, this seems to be the first approach in Northern Brazil aimed at assessing the immune status of the general, urban population to $\mathrm{HHV}-8^{49}$.

The overall HHV-8 seroprevalence (16.3\%) in the Belém low-income, urban communities is comparable to those observed for adult populations in Italy and Greece ${ }^{18,37,42,46}$, where seropositivity rates averaged $19.5 \%$. These similarities suggest that both crowding and poor sanitation, which are prevailing conditions in the resource poor study areas of Belém, do not seem to enhance the potential for HHV-8 transmission, as already demonstrated in previous studies. It should be pointed out, however, that a few investigations propose a direct relationship between poor socioeconomic condition and the potential for HHV-8 transmission ${ }^{29}$.

Unlike the comparison made above, local seroprevalence rates were much lower than those reported for endemic countries in Africa, as well as for hyperendemic Brazilian Amerindian remote communities ${ }^{1,3,33,40}$. The high prevalence in African countries might be explained by the fact that HHV-8 infection rates generally parallel KS disease which is known to be endemic in several parts of the continent, particularly East Africa. Among hyperendemic Amerindian tribes, where KS has not been reported, it has been postulated that transmission is probably oral rather than sexual. Moreover, it has been hypothesized that Indians' genetic homogeneity may permit more frequent transmission of HHV-8 than that in heterogeneous populations. Studies conducted in Southeastern Brazil by ZAGO et al..$^{48}$ (2000) found a $4.6 \%$ seroprevalence among blood donors, a rate which is lower than that yielded for the urban population of Belém, Brazil. Although such a difference may be related to the use of different serological assays between studies under comparison, it seems plausible to postulate that blood donor groups per $s e$ are at an inherently lower risk of becoming infected by HHV-8 than is the general population taken as a whole.

In this study, the overall prevalence rate of HHV-8 antibodies in children aged $\leq 10$ years $(12.0 \%)$ was found to be lower, as compared with data from several authors ${ }^{8,25,39}$. In spite of this, however, it can be concluded that, in Belém, Brazil, a significant proportion of HHV-8 infection occurs during childhood, suggesting horizontal transmission, perhaps among siblings, but also from mother to child ${ }^{34}$. The fact that there are progressively increasing prevalence rates with increasing age suggests endemicity of HHV-8 infection in the Belém urban communities. In this context, it is most likely that transmission through sexual route also play a role during adolescence and adulthood ${ }^{8,25,47}$. It is noticeable that antibody prevalence rate peaks - $33.3 \%$ - among adults aged $\geq 41$ years, including the elderly, and this raises the question on whether HHV8 reactivation may occur in addition to the largely proposed sexualand- nonsexual routes of transmission, particularly among the oldest persons ${ }^{4,11,22,30}$. Of note, in female subjects the pattern of antibody acquisition by age is similar to that of both gender groups taken together; however, among male individuals there was a significant decrease in seroprevalence rates from the group of individuals aged $\leq 10-20$ years to that of 21-40 years. Although this may have occurred by chance, mainly because of the small sample size, it could be hypothesized that sexual route transmission might play a major role in the latter age group, and men would be at lower risk of HHV-8 infection than women ${ }^{7}$.

It was observed that seropositivity rate in female adults aged 21-30 years was significantly higher than that for male individuals clustered in the same age group $(\mathrm{P}=0.02)$. Although there is currently no wellfounded explanation for this difference, one can postulate that women are at greater risk of HHV-8 infection, since this virus can be shed into semen and might be transmitted during sexual intercourse ${ }^{7}$. Conversely, shedding of HHV-8 into the genital tract of infected women is known to be uncommon, suggesting that female-to-male transmission is probably low ${ }^{47}$.

The progressive increase of geometric mean optical densities (GMODs) across age-groups essentially reflects the pattern of antibody acquisition as indicated by seroprevalence rates.

The results presented herein indicate that HHV-8 infection is endemic in the urban population of Belém, Brazil. It is suggested that a significant proportion of transmission occurs during childhood and that adult women may be at greater risk of HHV-8 infection than men. Further local studies are planned, focussing on the epidemiological features of HHV-8 infection in high-risk groups, for example, HIV-infected persons with KS.

\section{RESUMO}

\section{Prevalência de anticorpos para o herpesvírus humano tipo 8 na população de Belém, Pará, Brasil}

Amostras de soro de 497 crianças e adultos residentes em 2 bairros (Terra Firme e Guamá) de Belém, Pará, norte do Brasil foram examinadas com o propósito de detectar-se anticorpos para o herpesvírus 8, utilizandose a técnica imunoenzimática. A soroprevalência total nessas comunidades urbanas foi de $16,3 \%$. As taxas de prevalência de anticorpos para o HHV-8, considerando ambos os sexos, aumentou progressivamente através dos grupos de idade, variando de $12,0 \%$ a 33,3\%. Quando a soroprevalência é analisada por sexo, taxas similares são encontradas para os indivíduos do sexo feminino $(18,4 \%)$ e masculino $(14,0 \%)$. A taxa de prevalência no sexo feminino aumentou de $10,3 \%$, em crianças $\leq 10$ anos, para 30,0\% nos adultos de 41-50 anos. Já nos indivíduos do sexo masculino, a prevalência de anticorpos para o HHV-8 decresceu de $13,3 \%$, nas crianças/adultos de $\leq 10$ a 20 anos de idade, para $6,1 \%$ em adultos com 21-30 anos. Do grupo etário de 31-40 anos para frente, as taxas de soropositividade relativas ao sexo masculino aumentaram gradualmente de $8,3 \%$ a $66,7 \%$. Diferença significativa foi observada nas taxas de soropositividade relacionadas ao grupo etário de 21-30 anos, se comparados indivíduos dos sexos feminino e masculino: $23,3 \%$ e $6,1 \%$, respectivamente $(\mathrm{P}=0,03)$. A média geométrica das densidades óticas aumentaram progressivamente do menor para o maior grupo de idade. Nossos dados sugerem que a transmissão do HHV-8 ocorre com frequência na população de Belém e que a prevalência de anticorpos observada aumentou com a idade. 


\section{REFERENCES}

1. ARIYOSHI, K.; VAN DER LOEFF, S.M.; COOK, P. et al. - Kaposi's sarcoma in the Gambia, West Africa is less frequent in human immunodeficiency virus type 2 than in human immunodeficiency virus type 1 infection despite a high prevalence of human herpesvivus 8. J. hum. Virol., 1: 193-199, 1998.

2. BAHIA, F. \& BRITES, C. - Human herpes virus 8 and Kaposi's sarcoma: a review. Braz. J. infect. Dis., 3: 166-175, 1999.

3. BIGGAR, R.J.; WHITBY, D.; MARSHALL, V.; LINHARES, A.C. \& BLACK, F. Human herpesvirus 8 in Brazilian Amerindians: a hyperendemic population with a new subtype. J. infect. Dis., 181: 1562-1568, 2000.

4. BIGONI, B.; DOLCETTI, R.; DE LELLIS, L.; CARBONE, A. et al. - Human herpesvirus 8 is present in the lymphoid system of healthy persons and can reactivate in the course of AIDS. J. infect. Dis., 173: 542-549, 1996.

5. BLACKBOURN, D.J.; AMBROZIAK, J.; LENNETTE, E. et al. - Infectious human herpesvirus 8 in a healthy North American blood donor. Lancet, 349: 609-611, 1997.

6. BLACKBOURN, D.J.; LENNETTE, E.T.; AMBROZIAK, J.; MOURICH, D.V. \& LEVY, J.A. - Human herpesvirus 8 detection in nasal secretions and saliva. J. infect. Dis., 177: 213-216, 1998.

7. BLACKBOURN, D.J. \& LEVY, J.A. - Human herpesvirus 8 in semen and prostate. AIDS, 11: 249-250, 1997.

8. BLAUVELT, A.; SEI, S.; COOK, P.M.; SCHUlZ, T.F. \& JEANG, K.T. - Human herpesvirus 8 infection occurs following adolescence in the United States. J. infect. Dis., 176: 771-774, 1997.

9. CALABRÒ, M.L.; SHELDON, J.; FAVERO, A. et al. - Seroprevalence of Kaposi's sarcoma-associated herpesvirus/human herpesvirus 8 in several regions of Italy. $\mathbf{J}$. hum.Virol., 1: 207-213, 1998.

10. CATARINO-DE-ARAUJO, A.; CALABRÒ, M.L.; FAVERO, A. et al. - Detection of herpes virus (KSHV) DNA sequences in Brazilian patients with AIDS-associated Kaposi's sarcoma. Braz. J. infect. Dis., 1: 256-259, 1997.

11. CATtAni, P.; CAPUANO, M.; CERIMEle, F. et al. - Human herpesvirus 8 seroprevalence and evaluation of non-sexual transmission routes by detection of DNA in clinical specimens from human immunodeficiency virus-seronegative patients from central and southern Italy, with and without Kaposi's sarcoma. J. clin. Microbiol., 37: 1150-1153, 1999.

12. CHAN, P.K.S.; NG, H.K.; CHEUNG, J.L.K. \& CHENG, A.F. - Survey for the presence and distribution of human herpesvirus 8 in healthy brain. J. clin. Microbiol., 38: 2772-2773, 2000

13. CHANG, Y.; CESARMAN, E.; PESSIN, M.S. et al. - Identification of herpesvirus-like DNA sequences in AIDS-associated Kaposi's sarcoma. Science, 266: 1865-1869, 1994.

14. ENBOM, M.; SHELDON, J.; LENNETTE, E. et al. - Antibodies to human herpesvirus 8 latent and lytic antigens in blood donors and potential high-risk groups in Sweden: variable frequencies found in multicenter serological study. J. med. Virol., 62: 498$504,2000$.

15. FOX, J.D.; BRIGGS, M.; WARD, P.A. \& TEDDER, R.S. - Human herpesvirus 6 in salivary glands. Lancet, 336: 590-593, 1990.

16. FREITAS, R.B.; MONTEIRO, T.A.F. \& LINHARES, A.C. - Outbreaks of human-herpes virus 6 (HHV-6) infection in day-care centers in Belém, Pará, Brazil. Rev. Inst. Med. trop. S. Paulo, 42: 305-311, 2000.

17. GAO, S.J.; KINGSLEY, L.; LI, M. et al. - KSHV antibodies among Americans, Italians and Ugandans with and without Kaposi’s sarcoma. Nat. Med., 2: 925-928, 1996.
18. GESSAIN, A.; BRIÈRE, J.; ANGELIN-DUCLOS, C. et al. - Human herpes virus 8 (Kaposi's sarcoma herpes virus) and malignant lymphoproliferations in France: a molecular study of 250 cases including two AIDS-associated body cavity based lymphomas. Leukemia, 11: 266-272,1997.

19. GOEDERT, J.J.; KEDES, D.H. \& GANEM, D. - Antibodies to human herpesvirus 8 in women and infants born in Haiti and the USA. Lancet, 349: 1368, 1997.

20. HOWARD, M.R.; WHITBY, D.; BAHADUR, G. et al. - Detection of human herpesvirus 8 DNA in semen from HIV-infected individuals but not healthy semen donors. AIDS, 11: $15-19,1997$

21. INAGI, R.; KOSUGE, H.; NISHIMOTO, S.; YOSHIKAWA, K. \& YAMANISHI, K. Kaposi's sarcoma- associated herpesvirus (KSHV) sequences in premalignant and malignant skin tumors. Arch. Virol., 141: 2217-2223, 1996.

22. KELLER, R.; ZAGO, A.; VIANA, M.C. et al. - HHV-8 infection in patients with AIDSrelated Kaposi's sarcoma in Brazil. Braz. J. med. biol. Res., 34: 879-886, 2001.

23. KNOWLES, D.M. \& CESARMAN, E. - The Kaposi's sarcoma-associated herpesvirus (human herpesvirus-8) in Kaposi's sarcoma, malignant lymphoma, and other diseases. Ann. Oncol., 8: 123-129, 1997.

24. LA DUCA, J.R.; LOVE, J.L.; ABBOTT, L.Z. et al. - Detection of human herpesvirus 8 DNA sequences in tissues and bodily fluids. J. infect. Dis., 178: 1610-1615, 1998.

25. LENNETTE, E.T.; BLACKBOURN, D.J. \& LEVY, J.A. - Antibodies to human herpesvirus type 8 in the general population and in Kaposi's sarcoma patients. Lancet, 348: 858-861, 1996.

26. LINHARES, A.C.; GABBAY, Y.B.; MASCARENHAS, J.D.P. et al. - Immunogenicity, safety and efficacy of tetravalent rhesus-human, reassortant rotavirus vaccine in Belém, Brazil. Bull. Wld. Hlth. Org., 74: 491-500, 1996.

27. LUPPI, M.; BAROZZI, P.; MAIORANA, A. et al. - Frequency and distribution of herpesvirus-like DNA sequences (KSHV) in different stages of classic Kaposi's sarcoma and normal tissue from an Italian population. Int. J. Cancer, 66: 427-431, 1996.

28. MARTIN, J.N.; GANEM, D.E.; OSMOND, D.H. et al. - Sexual transmission and the natural history of human herpesvirus 8 infection. New Engl. J. Med., 338: 948-954, 1998

29. MAYAMA, S.; CUEVAS, L.E.; SHELDON, J. et al. - Prevalence and transmission of Kaposi's sarcoma-associated herpesvirus (human herpesvirus 8) in Ugandan children and adolescents. Int. J. Cancer, 77: 817-820, 1998.

30. MONINI, P.; COLOMBINI, S.; STURZL, M. et al. - Reactivation and persistence of human herpesvirus- 8 infection in B cells and monocytes by Th- 1 cytokines increased in Kaposi's sarcoma. Blood, 93: 4044-4058, 1999.

31. MONINI, P.; DE LELliS, L.; FABRIS, M.; RIGOLIN, F. \& CASSAI, E. - Kaposi's sarcoma-associated herpesvirus DNA sequences in prostate tissue and human semen. New Engl. J. Med., 334: 1168-1172, 1996.

32. NEIPEL, F.; ALBRECHT, J.C. \& FLECKENSTEIN, B. - Cell-homologus genes in Kaposi's sarcoma-associated Rhadinovirus human herpesvirus 8: determinants of its pathogenicity? J.Virol., 71: 4187-4192, 1997.

33. OLSEN, S.J.; CHANG, Y.; MOORE, P.S.; BIGGAR, R.J. \& MELBYE, M. - Increasing Kaposi's sarcoma-associated herpesvirus seroprevalence with age in a highly Kaposi's sarcoma endemic region, Zambia in 1985. AIDS, 12: 1921-1925, 1998.

34. PlANCOUlAine, S.; ABEL, L.; VAN BEVEREN, M. et al. - Human herpesvirus 8 transmission from mother to child and between siblings in an endemic population. Lancet, 356: 1062-1065, 2000.

35. RABKIN, C.S.; SCHULZ, T.F.; WHITBY, D. et al. - Interassay correlation of human herpesvirus 8 serologic tests. HHV-8 Interlaboratory Collaborative Group. J. infect. Dis., 178: 304-309, 1998 
36. SAID, W.; CHIEN, K.; TAKEUCHI, S. et al. - Kaposi's sarcoma-associatad herpesvirus (KSHV or HHV-8) in primary effusion lymphoma: ultrastructural demonstration of herpesvirus in lymphoma cells. Blood, 87: 4937-4943, 1996.

37. SCHULZ, T.F. - Kaposi's sarcoma-associated herpesvirus (human herpesvirus 8). J. gen. Virol., 79: 1573-1591, 1998.

38. SCHULZ, T.F.; SHELDON, J. \& GREESILL, J. - Kaposi's sarcoma associated herpesvirus (KSHV) or human herpesvirus 8 (HHV-8). Virus Res., 82: 115-126, 2002.

39. SIMPSON, G.R.; SCHULZ, T.F.; WHITBY, D. et al. - Prevalence of Kaposi's sarcoma associated herpesvirus infection measured by antibodies to recombinant capsid protein and latent immunofluorescence antigen. Lancet, 348: 1133-1138, 1996.

40. SITAS, F.; CARRARA, H.; BERAL, V. et al. - Antibodies against human herpesvirus 8 in black South African patients with cancer. New Engl. J. Med., 340: 1863-1871, 1999.

41. SOSA, C.; KLASKALA, W.; CHANDRAN, B. et al. - Human herpesvirus 8 as a potential sexually transmitted agent in Honduras. J. infect. Dis., 178: 547-551, 1998.

42. TOULOUMI, G.; KAKLAMANIS, L.; POTOURIDOU, I. et al. - The epidemiologic profile of Kaposi's sarcoma in Greece prior to and during the AIDS era. Int. J. Cancer, 70: 538-541, 1997.

43. VITALE, F.; VIVIANO, E.; PERNA, A.M. et al. - Serological and virological evidence of non- sexual transmission of human herpesvirus type 8 (HHV-8). Epidem. Infect. 125: $671-675,2000$
44. WABINGA, H.R.; PARKIN, D.M.; WABWIRE-MANGEN, F. \& MUGERWA, J.W. Cancer in Kampala, Uganda, in 1989-91: changes in incidence in the era of AIDS. Int. J. Cancer, 54: 26-36, 1993.

45. WHITBY, D.; HOWARD, M.R.; TENANT-FLOWERS, M. et al. - Detection of Kaposi sarcoma associated herpesvirus in peripheral blood of HIV-infected individuals and progression to Kaposi's sarcoma. Lancet, 346: 799-802, 1995

46. WHITBY, D.; LUPPI, M.; BAROZZI, P. et al. - Human herpesvirus 8 seroprevalence in blood donors and lymphoma patients from different regions of Italy. J. Nat. Cancer Inst., 90: 395-397, 1998.

47. WhitbY, D.; SMITH, N.A.; MATTHEWS, S. et al. - Human herpesvirus 8: seroepidemiology among women and detection in the genital tract of seropositive women. J. infect. Dis., 179: 234-236, 1999.

48. ZAGO, A.; BOURBOUliA, D.; VIANA, M.C. et al. - Seroprevalence of human herpesvirus 8 and its association with Kaposi sarcoma in Brazil. Sex. transm. Dis., 27: 468-472, 2000.

49. ZHANG, X.; FITZPATRICK, L.; CAMPBELL, T.B. et al. - Comparison of the prevalence of antibodies to human herpesvirus 8 (Kaposi's sarcoma-associated herpesvirus) in Brazil and Colorado. J. infect. Dis., 178: 1488-1491, 1998.

Received: 08 August 2002

Accepted: 23 September 2002 